\title{
Skrotal Radyoterapide Curcuminin Profilaktik Kullanımı Testis Dokusunda PARP-1 İmmünreaktivitesini ve Spermatogenezi Nasıl Etkiler?
}

\section{How the Profilactic Usage of Curcumin Affects the Parp-1 Immunoreactivity And Spermatogenesis in Scrotal Radiotherapy?}

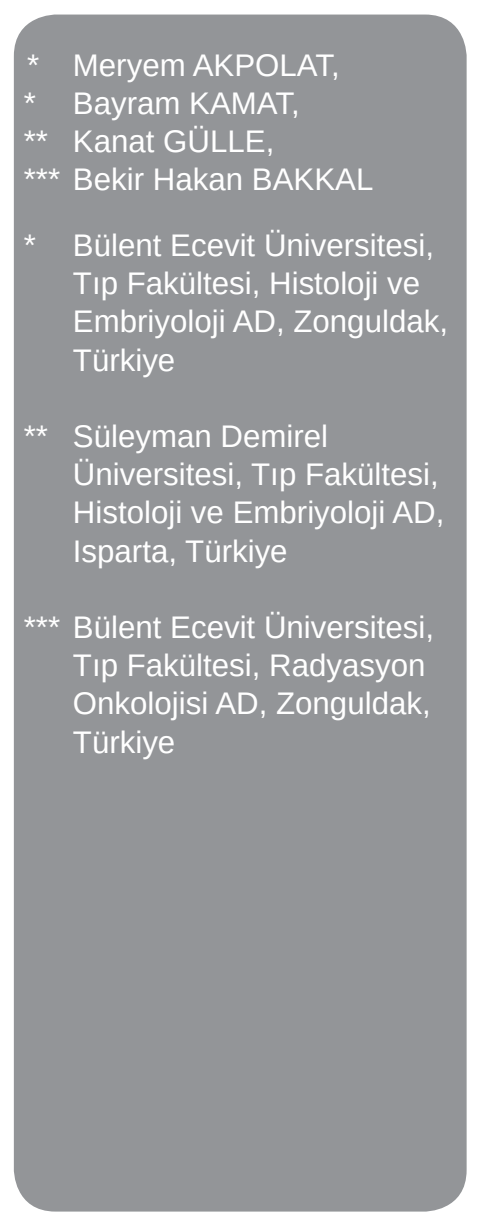

Yazışma Adresi:

Doç. Dr. Meryem Akpolat

Bülent Ecevit Üniversitesi,

Tıp Fakültesi, Histoloji ve

Embriyoloji Anabilim Dalı,

Zonguldak, Türkiye

Tel: 05354325163

e-mail:

meryemakpolat@yahoo.com

\section{Öz}

Fertilitede akut doz radyasyonun öldürücü etkileri iyi bilinmektedir. Kısa süreli radyasyona maruziyet germ hücrelerinin ölümü ve hasarlanması neticesinde infertilite ile sonuçlanır. Son yıllarda radyoterapi, kanserli hastaların uzun süreli iyileşmesine önemli ölçüde katkı vermiştir. Ancak radyasyonun uzun dönemde üreme sistemi üzerindeki hasarlayıcı etkisi ile meydana gelen fertilizasyon kayıplarını göz ardı etmemek gerekmektedir. Bu güne kadar curcuminin antioksidan ve radyoprotektif etkisi ile ilgili birçok makale yayınlanmıştır. Bu çalışma; curcuminin X ışınlamayı takiben sıçan testisinde ortaya çıkacak germ hücre kaybı ile ilişkili infertiliteyi iyileştirebileceği düşüncesi ile planlanmıştır. Bu deneysel çalışmada biri kontrol 3'ü deney grubu olmak üzere toplam 4 grup oluşturuldu. Radyasyon hasarı oluşturmak amacıyla kontrol ve curcumin grubu dışındaki deneklerin skrotal bölgelerine tek seferde 6 Gy $X$ ışını uygulandı. Curcumin ve radyasyon+ curcumin gruplarına; ışınlamadan 1 hafta önce başlayarak, haftada 3 kez olmak üzere 7 hafta boyunca oral yoldan $100 \mathrm{mg} / \mathrm{kg}$ curcumin, kontrol ve radyasyon gruplarına da aynı şekilde çeşme suyu verildi. Işınlamadan 6 hafta sonra tüm denekler sakrifiye edildi ve alınan testis biyopsi materyalleri histopatolojik incelemeler için işlemlendirildi. Bu çalışmada iyonize radyasyonun tübüllerin çoğunda germ hücre kaybına bağlı olarak, tübüler atrofiye neden olduğu görüldü. Radyasyon alan deneklerin tümünde, spermatogenezisin bozulması ile ilişkili olarak, Jhonsen skorunda kontrole göre anlamlı düzeyde azalma saptandı. PARP-1 immünreaktivite skorunda da hasarının şiddeti ile ilişkili olarak, kontrole göre anlamlı düzeyde artış belirlendi. Curcumin uygulamasının ise radyasyona bağlı ortaya çıkan hasarları önlemede beklenen düzeyde koruma ve iyileşme sağlamadığı tespit edildi.

Anahtar kelimeler: İyonize-radyasyon, Curcumin, PARP-1, Spermatogenez

\section{Abstract}

The lethal effects of acute doses of radiation on fertility are well known. Germ cells are killed or damaged within a short time of exposure to radiation. In recent years, radiotherapy of patients with cancer has led to an increased number of sustained remissions. However, among the long-term side effects of radiation, injury to the reproductive system is of particular concern. Many papers have been reported so far on the antioxidant effect of curcumin. The present study, we hypothesized that curcumin can minimize germ-cell deple- 
tion and morphological features of late cell damage in the rat testis following $X$-irradiation. The animals were divided into 4 groups: the first group was the control and the other three were the experimental groups. 6 Gy $X$ ray in a single fraction was applied into the scrotal areas of the subjects except the control and curcumin groups in order to form radiation damage. The rats in the second and forth groups were given curcumin (a dose of $100 \mathrm{mg} / \mathrm{kg}$ body weight) orally three times a week during a seven-week period, beginning the week before radiation therapy. The rats in the first and third groups received tap water in the same way. Testis biopsy samples from the all groups were taken on the 7th week. All samples were processed and observed at the light microscopic levels.

In the present study, radiation exposure caused severe degenerative changes in testes. Spermatogenesis had arrested in seminiferous tubules and the majority of the tubules were found to be atrophic, absent of germ cells. It was identified that curcumin hadn't been effective in the prevention of all damages caused by radiation.

Keywords: Ionizing-radiation, Curcumin, PARP-1, Spermatogenesis.

\section{Giriş}

İnsanoğlu varoluşundan bu yana doğal radyasyonla sürekli etkileşim içinde olmuş, gelişen teknoloji ile de yapay radyasyon hayatın ayrılmaz bir parçası haline gelmiştir. Sağlık alanında radyasyondan faydalanılarak tanı ve tedavilerde kullanılmak üzere birçok cihaz üretilmiştir. Bu gelişmeler ile birlikte, tanısal inceleme ve tedavi sırasında alınan radyasyonun insan sağlığı üzerindeki etkileri önemli bir araştırma konusu haline gelmiştir. Radyasyon, hücreyi oluşturan tüm temel elemanlarda hasara neden olur ve miktarı ne olursa olsun, deoksiribonükleik asit (DNA) yapısına zarar verebilir $(1,2)$. İyonize radyasyon hem direkt DNA da tek ve çift zincir kırıkları oluşturarak hem de reaktif oksijen radikalleri oluşturarak indirekt yoldan hücre hasarına ve ölümüne neden olur. (3).

Gençlerde yaygın olarak görülen testis kanseri tedavisinde radyoterapi sıklıkla tercih edilen bir tedavi yöntemidir. Testis kanseri tedavisinde germ hücreleri radyoterapiden etkilenir ve bu tedavinin sonucunda ciddi bir problem olan kalıcı veya geçici infertilite ortaya çıkar. Kalıcı infertilite sadece spermatogonyumların yok olmasıyla değil, farklılaşma özelliğini (spermatogenez) kaybetmesiyle de oluşabilir $(4,5)$.

Spermatogenez; seminifer tübüllerin duvarında buIunan spermatogonyumların önce mitozla çoğalıp, ardından mayoz bölünme geçirerek kromozom sayısının yarıya indiği ve spermatozoonlara farklandığı kompleks bir süreçtir. Bu sürecin başında yer alan spermatogonyumlar radyasyona karşı çok duyarlıdırlar. Düşük doz (0,1 Gy) radyasyon uygulamalarında dahi hücresel hasarın başladığı bildirilmiştir.(6).

Testis kanseri tedavisinden önce, ergin hastalarda gereken durumlarda kullanılmak amacıyla spermler dondurulabilir. Ancak, ergenlik çağına gelmemiş hastalarda bu durum mümkün değildir (7). Bu yüzden testis kanseri tedavisi sırasında oldukça hassas olunmalı ve alternatif tedaviler geliştirilmeye çalışılmalıdır. Çünkü testis kanseri tedavisi alan puberteye girmemiş hastaların ileride çocuk sahibi olmak istemeleri muhtemeldir. Tedavi sırasında radyasyonun yol açtığı oksidatif stresten, sağlıklı üreme hücrelerinin korunması gerekmektedir. Radyoterapi esnasında normal doku korunmasının, kanser hücrelerinin tahribatı kadar önemli olduğunun gösterilmesiyle, korunma araştırmaları üzerine odaklanmış çalışmalar yapılmıştır (8).

Antioksidan özellik gösteren proflaktik maddelerden biride curcumindir. Curcumin; Çin ve Hindistan'da yaygın olarak yetiştirilen, Zingiberaceae familyasına ait, sarıçiçekli ve büyük yapraklı Curcuma longa bitkisinin rizomlarından (köklerinden) elde edilir. Aktive olmuş makrofajlardan salınan nitrik oksit, hidrojen peroksit, süperoksit radikallerini süpüren etkili bir antioksidandır. Serbest radikalleri tutma özelliğinden dolayı DNA'yı oksidatif hasardan korur. Curcuminin radyasyona karşı koruyucu etkisi büyük oranda serbest radikalleri süpürme özelliğinden kaynaklanır $(8,9)$. Curcuminin antioksidan ve radyoprotektif özelliklerinin vurgulandığı pek çok çalışma bulunmaktadır (10-13).

Radyasyon uygulanan dokuda ortaya çıkan DNA kırıklarının tamir mekanizması moleküler düzeyde 
incelendiğinde, Poli ADP Riboz Polimeraz (PARP) ailesi proteinleri karşımıza çıkmaktadır. Poli ADP Riboz Polimeraz-1 (PARP-1) proteinlere poli ADP-riboz (PAR) grupları ekleyerek bu proteinlerin fonksiyonlarını düzenler, bu proteinler ise DNA ya bağlanır. PARP ailesinin birçok üyesi olsa da, hücresel poli ADP-ribozilasyonun \%90'ı PARP-1 tarafından gerçekleştirilmektedir. PARP-1, nükleusta bol miktarda bulunan, DNA zincir kırıkları oluştuğu takdirde aktive olan ve fonksiyonel olarak DNA tamiriyle ilişkili olan bir enzimdir (14).

Spermatogenez sırasında PARP-1'in etkin bir rol üstlendiği tespit edilmiştir. Spermatogenezde, birinci mayoz bölünmenin profaz aşamasında DNA kırıkları meydana gelebilir. Ayrıca farklılaşan spermatidlerde kromatinin paketlenmesi sırasında da DNA kırıkları ortaya çıkabilmektedir. Oluşan bu kırıklar, genetik farklılıkların doğru bir şekilde aktarılabilmesi için, tamir edilmelidir. Bu açıdan, insan germ hücresi farklılaşmasında PARP-1 hayati bir rol oynamaktadır (15). Bu sonuçlarla PARP-1 in genomik bütünlükte çok önemli koruyucu bir görevi olduğunu ve spermatogenez sırasında aktif olarak rol oynadığını söylenebilir. Doğal süreçde spermatogenez sırasında zaten aktif olan PARP-1'in testiküler radyoterapi uygulaması ile açığa çıkacak DNA kırıklarının onarımı için de sahneye çıkacağı düşünüldüğünde, dokudaki ekspresyon seviyesinin belirlenmesi önem arzetmektedir.

Bu deneysel çalışmanın amacı skrotal X ışını uygulamasının neden olduğu hücresel hasarı önlemede curcuminin etkisini histopatolojik, histomorfometrik ve immünohistokimyasal yöntemler ile saptamayı, ayrıca iyonize radyasyona bağlı spermatogenez sürecinde, PARP-1 immünreaktivitesindeki değişiklikleri araştırmaktır.

\section{Gereç ve Yöntem}

\section{Deney Hayvanı}

Çalışmamızda Bülent Ecevit Üniversitesi Deney Hayvanları Araştırma Birimi'nde üretilen, 2,5-3 aylık, ağırlıkları 200-300 g arasında değişen 40 adet erkek Wistar albino sıçan kullanıldı. Biri kontrol 3'ü deney grubu olmak üzere toplam 4 grup oluşturuldu. Tüm denekler, deney süresi boyunca optimum laboratuar koşulları (22 \pm 1 oC, 12 saat aydınlık/karanlık siklusunda) altında, günlük içme suyu ve $\% 21$ ham protein içeren pelet yemlerle beslendi.

\section{Radyasyon Uygulaması}

Radyasyon hasarı oluşturmak amacıyla tüm denekler Bülent Ecevit Üniversitesi Tıp Fakültesi Radyasyon Onkolojisi Anabilim Dalı' na götürüldü. Kontrol grubu ve Curcumin grubu hariç, Radyasyon ve Radyasyon+Curcumin gruplarındaki her bir denek, intraperitonel (i.p.) yoldan $90 \mathrm{mg} / \mathrm{kg}$ ketamin (Ketalar-Eczacıbaşı/ Türkiye), 10 mg/kg xylazine (Rompun-Bayer/Türkiye) ile uyutulduktan sonra, supin (sırt üstü) pozisyonunda sabitlendi. Linear akseleratör cihazı kullanılarak, iki testisi içeren skrotal bölge $5 \times 5 \mathrm{~cm}$ ebadında simüle edildi. Doz hesaplamaları yapılarak skrotal bölgeye tek seferde 6 Gy X ışını uygulandı.

\section{Deney Grupları}

Kontrol Grubu ( $n=10)$ : Haftada 3 kez olmak üzere, toplam 7 hafta boyunca oral yoldan çeşme suyu uygulandı.

Curcumin Grubu ( $n=10)$ : Haftada 3 kez olmak üzere, toplam 7 hafta boyunca oral yoldan $100 \mathrm{mg} / \mathrm{kg}$ curcumin uygulandı.

Radyasyon Grubu ( $n=10)$ : Skrotal bölgeye 6 Gy X ışını uygulaması yapıldı. Ayrıca ışınlamadan 1 hafta önce başlayarak haftada 3 kez olmak üzere toplam 7 hafta boyunca oral yoldan çeşme suyu uygulandı. Radyasyon+Curcumin Grubu ( $n=10)$ : Skrotal bölgeye 6 Gy X ışını uygulaması yapıldı. Ayrıca ışınlamadan 1 hafta önce başlayarak haftada 3 kez olmak üzere toplam 7 hafta boyunca oral yoldan $100 \mathrm{mg} / \mathrm{kg}$ curcumin uygulandı.

Işınlamadan 6 hafta sonra, ketamin-xylazin anestezisi altında tüm denekler sakrifiye edildi. Deney süresi boyunca ağırık takibi yapılan deneklerin, deney sonunda testis ağırlıkları da ölçülerek, her bir grup için ortalama testis ağırlığı (g)/100 g vücut ağırığı hesaplandı.

\section{Histopatolojik ve Histomorfometrik Analizler}

Işık mikroskobik incelemeler için, her deneğin testis dokusu BEÜ Tıp Fakültesi Histoloji ve Embriyoloji Anabilim Dalı Işık Mikroskopi Laboratuar'ında formol 
fiksatöründe fikse edilip, parafin inklüzyonu yapılarak bloklandı. Bu bloklardan alınan $5 \mu \mathrm{m}$ kalınlığındaki kesitlere, testisin histolojik yapı özelliklerini ortaya koyan Hematoksilen-Eozin ( $\mathrm{H}-\mathrm{E})$, Periodik Asit-Schiff (PAS) ve Masson boyaları uygulandı. Işık mikroskobunda bulguların fotoğrafları çekildi.

Testislerde seminifer tübül çapı ve seminifer epitel yüksekliği ölçüldü. Ölçümler, her denek için 3 testis kesitinde ve her kesitten yuvarlak veya yuvarlağa yakın 10 tübülün enine kesiti üzerinde toplam 30 tübül değerlendirilerek yapıldı (16).

\section{Johnsen Skoru ile Spermatogenezin Değerlendirilmesi}

Testiste seminifer tübül duvarında spermatogenezin değerlendirilmesi Johnsen kriterlerine göre yapıldı (Tablo 1). Bu puanlama sistemine göre incelenecek olan seminifer tübül kesitlerine verilecek puanların toplamı, sayılan tübül sayısına bölünerek ortalama puan hesaplandı (17).

\section{İmmünohistokimyasal Analiz}

Radyasyona bağlı ortaya çıkan DNA hasarının gös- tergesi olarak testis dokusunda DNA onarıcı bir enzim olan PARP-1 ekspresyonu immünohistokimyasal yöntem ile gösterildi.

İmmünohistokimyasal boyamalar için parafin bloklardan elde edilen $5 \mu \mathrm{m}$ kalınlığındaki kesitler, polilizin kaplı lamlara alındı. Deparafinizasyon işlemi için etüve alınan kesitler sonra 15'er dakikalık iki ksilol banyosundan geçirildi. Hidratasyon için, 5'er dakika süre ile $\% 100,96 \%, 90 \%, 70 \%$ ' lik alkol serilerinden geçirilen kesitler, distile suya alındı. Daha sonra 5'er dakikalık üç banyo şeklinde fosfat tamponu solüsyonunda (PBS; pH 7-7.2 yıkandı. Antijenik bağlanma bölgelerinin açığa çıkarılması amacı ile kesitler sitrat tamponuna ( $\mathrm{pH}$ : 6.0) alındı ve mikrodalga fırında 5 dakika kaynatıldıktan sonra soğumaya bırakıldı. Ardından kesitlerin çevresi pap pen ile çizildi önce distile su sonrada PBS ile yıkandı. Nemli kabine alınan kesitler endojen peroksidaz aktivitesinin giderilmesi amacıyla \% 3'lük hidrojen peroksit ile 15 dakika oda sıcaklığında inkübe edildi. Distile sudan geçirilen kesitler PBS ile yıkandı. Spesifik olmayan antikor bağlanmalarını bloklamak üzere kesitlere $\% 1$ preimmün rabbit serum (Ultra V Block, LabVision, TA-015-UB) uygulandı.

\begin{tabular}{|c|l|}
\hline $\begin{array}{c}\text { Johnsen } \\
\text { Skoru }\end{array}$ & \multicolumn{1}{c|}{ Johnsen Kriterleri } \\
\hline 10 & Germ epiteli çok tabakalı, açık santral lümen, çok miktarda spermatozoa. \\
\hline 09 & $\begin{array}{l}\text { Germ epiteli çok tabakalı ancak disorganize, lümendeki epitel hücreleri spermatozoalarla } \\
\text { karışmış. }\end{array}$ \\
\hline 08 & Germ epiteli çok tabakalı, lümende 10'dan daha az spermatozoa. \\
\hline 07 & Çok miktarda spermatid, ancak hiç spermatozoa yok. \\
\hline 06 & Hiç spermatazoon yok, spermatid sayısı 10'dan daha az. \\
\hline 05 & Bir kaç tane spermatosit, spermatid veya spermatozoa yok. \\
\hline 04 & Spermatozoa ve spermatid hiç yok, spermatosit sayısı 5'den az. \\
\hline 03 & Sadece bir kaç spermatogonyum. \\
\hline 02 & Bir kaç Sertoli hücresi, germ hücresi hiç yok. \\
\hline 01 & Seminifer tübülde hiç hücre yok. \\
\hline
\end{tabular}


Daha sonra kesitler nemli kabin içinde 1/100 oranında dilüe edilmiş primer antikor (Rabbit polyclonal IgG PARP-1, Kat. No. Ab6079, Abcam, USA) ile 1 saat inkübe edildi. Ardından PBS de (3X5 dk) yıkandı. Nemli kabine yerleştirilen kesitler $30 \mathrm{dk}$ sekonder antikor (Dako Biotinylated Link, K0609) ile muamele edildi. $\mathrm{Bu}$ işlemin hemen ardından PBS'le (3X5 dk) yıkanıp streptavidin (Streptavidin HRP, Dako, K0609) damlatılıp 10 dakika inkübe edildi. Bu uygulamadan sonra da PBS ile (3X5 dk) yıkama yapıldı. Nemli kabindeki kesitlere kromojen damlatıldı [3',3-diaminobenzidine (DAB), Vector, SK-4100]. Mikroskop başında boyanma kontrolü sağlandıktan sonra (3 dk), kromojen reaksiyonunu kesmek için kesitler distile suya alındı. Yıkamanın ardından 30 sn Mayer'in Hematoksilen'i (Bio-optica, 0506002/L) ile zıt boyama yapıldı. Akarsuda 5 dk yıkanan kesitler balsam kullanılarak (Merk) lamel ile kapatıldı ve ışık mikroskobunda semikantitatif olarak histolojik skorlama (H-skor) yapılarak değerlendirildi.

\section{İstatistiksel Analiz}

İstatistiksel değerlendirme SPSS 18.0 (SPSS Inc., Chicago, IL, USA) programı kullanılarak yapıldı. Tanımlayıcı istatistikler medyan (Q1-Q3) olarak ifade edildi. Dört grubun karşılaştırılmasında Kruskal-Wallis varyans analizi kullanıldı. Kruskal-Wallis varyans analizinde alt grupların ikişerli karşılaştırılması ise Bonferroni düzeltmeli Mann-Whitney $U$ testi ile yapıldı. Tekrarlı ölçümlerin değerlendirilmesinde ise Friedman testinden faydalanıldı. Alt grupların ikişerli karşılaştırılması Bonferroni düzeltmeli Wilcoxon testi ile yapıldı. Sonuçlar \% 95 güven aralığında değerlendirildi ve $p<0.05$ değeri anlamlı kabul edildi.

\section{Bulgular}

Kontrol ve deney gruplarından alınan testis biyopsilerinde, parankim ve stromal yapılar, morfolojik, immünohistokimyasal, morfometrik ve histopatolojik skorlama yöntemleri kullanılarak ışık mikroskopik düzeyde kıyaslanarak incelendi.

\section{Kontrol ve Curcumin Grubuna Ait Genel Morfolojik Bulgular}

Kontrol ve Curcumin grubu deneklere ait, testis doku kesitlerinin ışık mikroskopik incelemesinde, seminifer tübüllerin çok katlı kübik epitel ile döşeli olduğu, tübül duvarının spermatogenetik hücre serileri ile Sertoli hücrelerinden oluştuğu görüldü. Sertoli hücreleri soluk boyanan, karakteristik nükleus şekilleri (piramit, armut, üçgen veya oval) ile ayırd edildi. Bazal lamina üzerine oturan Sertoli hücrelerinin lateral katlantıları arasına yerleşik çok sayıda normal morfolojide, spermatogenetik seri hücreleri bulunmakta idi. Oval biçimli nükleusa sahip spermatogonyumlar bazal laminaya yakın olarak izlendi. Primer spermatositler, spermatogonyumların hemen üzerinde, 4n DNA'ya sahip olmaları nedeniyle daha büyük hacimli nükleusları ile ayırd edildiler. Gelişme evrelerine bağlı olarak sekonder spermatosit ve spermatidlerin daha üst sıralarda yer aldığı görüldü. Nükleusun üzerine oturmuş kep şeklinde PAS pozitif akrozom yapısıyla erken spermatidler, lümene uzanan iplik tarzında kuyrukları ve koyu uzun başlarıyla spermatozoalara dönüşecek olan geç spermatidler ayırt edildi. Pek çok seminifer tübül lümeninde spermatozoonlara rastlandı (Şekil 1: a-f).

Seminifer tübül epitelinin en dıştan tunika propriya ile sarıldığı görüldü. Miyoid hücreler, tunika propriyanın ortasında, bu dokuya paralel uzanan koyu boyanmış iğ şeklindeki uzun nükleusları ile ayırd edildi (Şekil 1: b, e).

Seminifer tübüller arasındaki interstisyel dokuda; kan damarları etrafında yerleşik, gevşek kromatinli nükleusa sahip, oval ya da yuvarlak şekilli, Leydig hücreleri ile lenf kapilerleri ve bağ doku hücreleri gözlendi (Şekil 1: b, e).

\section{Radyasyon ve Radyasyon+Curcumin Grubuna Ait Genel Morfolojik Bulgular}

Radyasyon grubundaki deneklerin testis dokularının ışık mikroskopik incelemelerinde; ışınlamaya bağlı olarak ortaya çıkan tübüler dejenerasyon, tübül çaplarındaki azalma ile dikkati çeken tübüler atrofi belirgin olarak gözlenmekte idi. Tübülerde çeşitli büyüklüklerde vakuolizasyonlara ve yer yer dikkat çeken çok nükleuslu dev hücrelere rastlandı. Tübüllerde spermatogenetik seri hücrelerinin çoğunun ortadan kalktığı, sadece bazalde birkaç spermatogonyum ile Sertoli hücrelerinin varlığını sürdürdüğü görüldü. Sertoli hücrelerinin nükleus şekillerinin düzensizleştiği ve zaman zaman bazal membrandan uzakta, tübül lümenine yakın yerleşim gösterdikleri dikkati çekmek- 

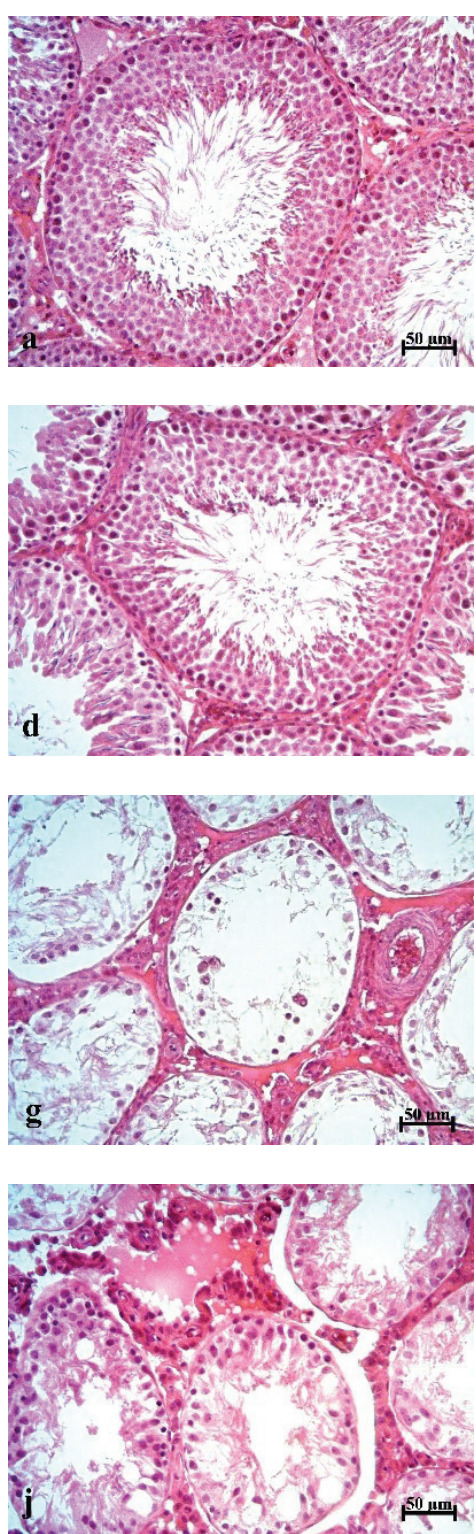
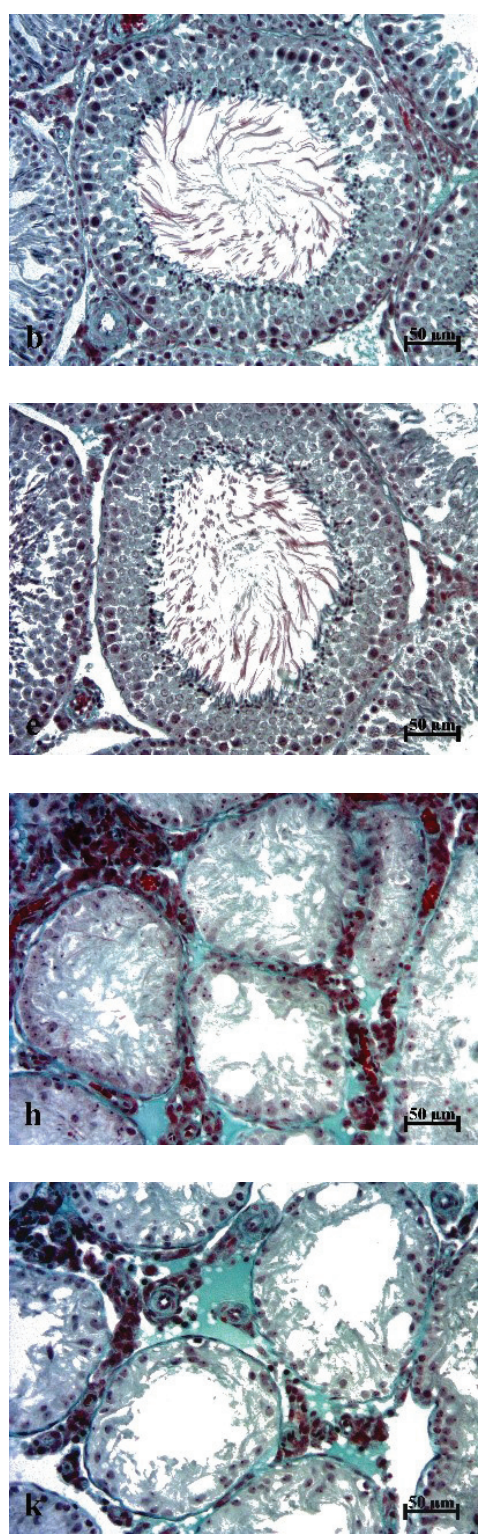
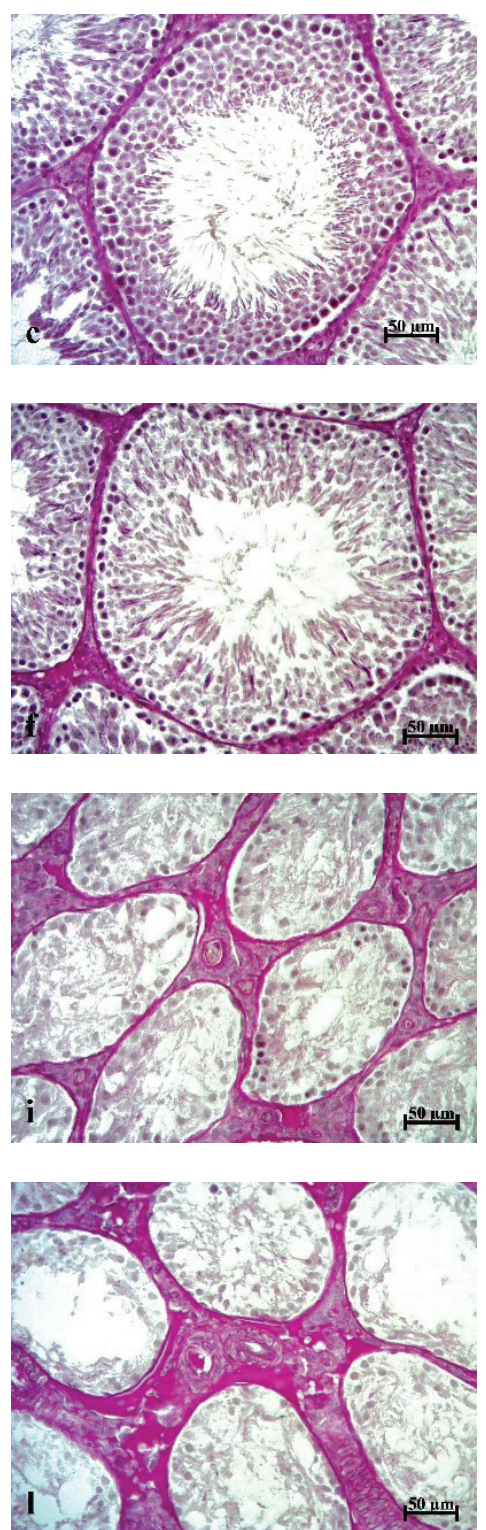

Şekil 1. Testis seminifer tübüllerine ait $\mathrm{H}-\mathrm{E}(\mathrm{a}, \mathrm{d}, \mathrm{g}, \mathrm{j})$, Masson (b, e, h, k) ve PAS (c, f, i, l) boyaları ile boyanmış preparatlardan elde edilen mikrograflar. (a-c) Kontrol grubuna ait sıçan testisi; çok katlı kübik epitel görünümünde, lümeni spermatozoalar ile dolu normal morfolojide, seminifer tübül ve etrafındaki interstisyum izlenmekte. (d-f) Curcumin grubuna ait sıçan testisi; normal morfolojik yapı özellikleri segileyen seminifer tübül ve interstisyum görülmekte. (g-i) Radyasyon grubuna ait sıçan testisi (ışınlamadan sonraki 6. hafta); seminifer tübül çaplarında ve seminifer epitel yüksekliğinde ciddi azalma, germinal epitelde vakuolizasyon, çok belirgin hücre kaybı, tübüllerde sadece birkaç spermatogonyum ile çok sayıda Sertoli hücresinin varlığı, tübüllerin etrafındaki bazal laminada kalınlaşma, interstisyel sahada hücre yoğunluğunda ve vaskülarizasyonda artış ile peritübüler hyalinizasyon izlenmekte. (j-I) Radyasyon+Curcumin grubuna ait sıçan testisi (ışınlamadan sonraki 6. hafta); seminifer tübüllerde Sertoli hücreleriyle birlikte spermatogonyumlar görülmekle birlikte bazı tübüllerde rejeneratif değişiklikler dikkati çekmekte. Tübüler bazal lamina kalınlaşması, interstisyumda hücre yoğunluğunda ve vaskülarizasyonda artış ile peritübüler hyalinizasyon bu grupta da izlenmekte. Bar: 50 um 
teydi (Şekil 1: g-i). Tübüllerin enine kesit görüntülerinde, bazal membran kalınlaşması (Şekil 1: i) ile birlikte tübüler atrofi nedeniyle interstisyel bağ dokusundan ayrılmalar saptandı. Interstisyel bağ dokuda gözlenen hücre yoğunluğu ve vaskülarizasyondaki artış ile peritübüler hyalinizasyon dikkat çekiciydi (Şekil 1: h). Radyasyon+Curcumin grubundaki deneklerin testis dokularının ışık mikroskopik incelemelerinde; ilk göze çarpan seminifer tübüllerde spermatogenetik hücre serisinde bir miktar artış olduğu idi. Bazı tübüllerde spermatogenetik hücre serilerinin kısmen düzenli yerleşim gösterdiği saptandı. Radyasyon grubuna benzer şekilde seminifer tübüllerin bir kısmı Sertoli hücreleri ve az sayıda spermatogonyumları içermekteydi, ayrıca tübüler atrofinedeniyle interstisyumdan ayrılmalar izlendi. (Şekil 1: j-I) Dejeneratif ve rejeneratif tübüllerin kalınlaşmış bazal membran ile çevrili oldukları, kuvvetli PAS pozitif görünümleri ile dikkat çekti (Şekil 1: I). İnterstisyel sahada yoğunluk ve vaskülarizasyon artışı bu grupta da gözlendi (Şekil 1: k).

\section{Kontrol ve Deney Gruplarında PARP-1 İmmünre- aktivitesinin Değerlendirilmesi}

Tüm deneklerin testis dokusunda, immünohistokimyasal yöntem ile PARP-1 ifadesi değerlendirildiğinde; özellikle spermatogonyumlarda farklı boyanma oranlarında (zayıf-orta-kuvvetli) PARP-1'in ifade edildiği saptandı. Interstisyumda ise PARP-1 ifadesine neredeyse hiç rastlanmadı (Şekil 2).

Testis doku kesitlerinde radyasyona karşı çok duyarlı hücreler olmaları nedeniyle, yalnızca spermatogonyumlar histolojik skorlama (H-skor) yöntemi ile semikantitatif olarak değerlendirildi. Histolojik skorlama, tübüllerde yer alan rast gele belirlenen 100 spermatogonyumun PARP-1 immünoreaktivite şiddeti değer-
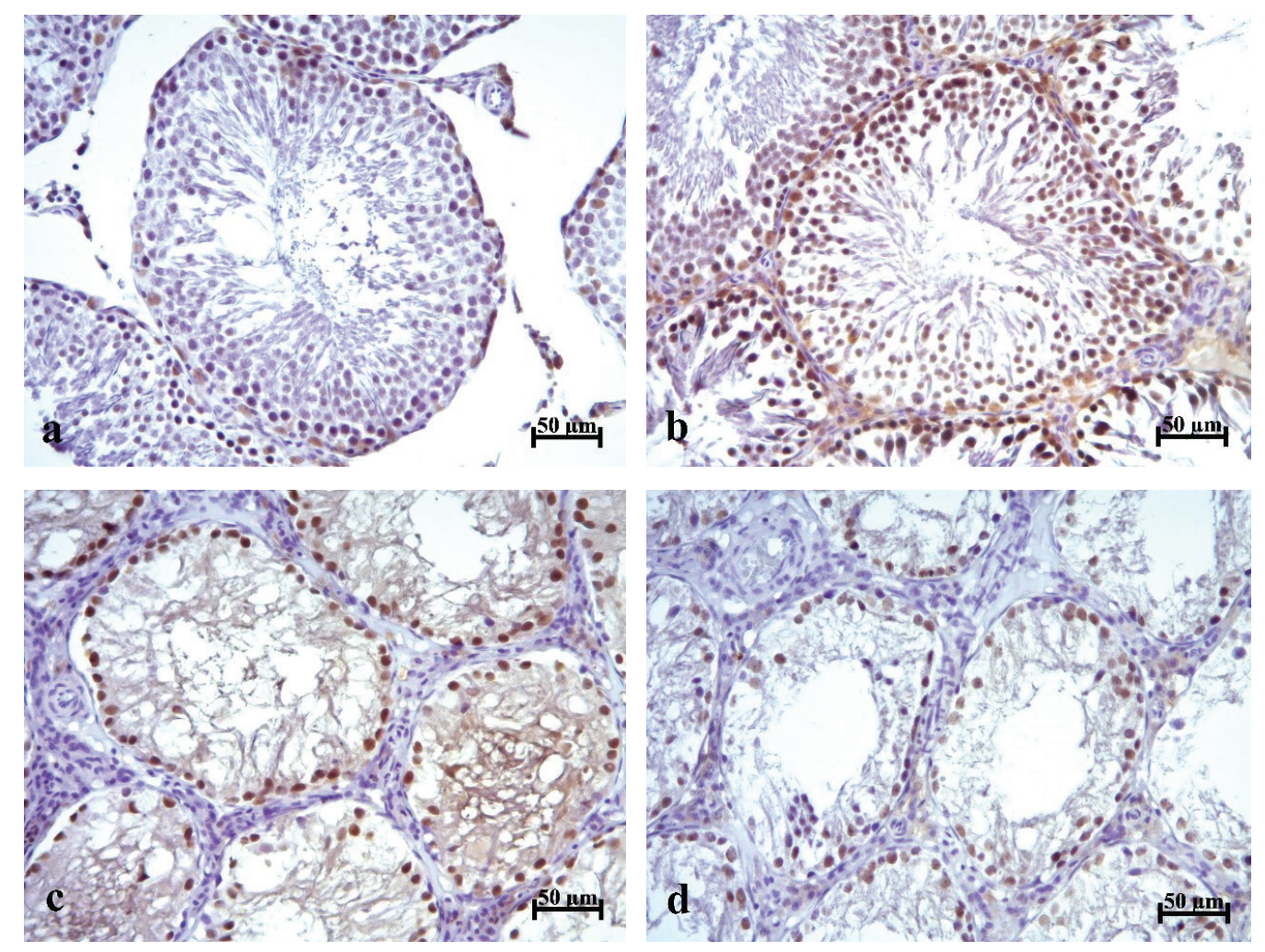

Şekil 2. Testis seminifer tübüllerinde PARP-1'in immünohistokimyasal olarak ifadesi. (a) Kontrol grubu. (b) Curcumin grubu. (c) Radyasyon grubu. (d) Radyasyon+Curcumin grubu. Bar: $50 \mu \mathrm{m}$. 
lendirilerek gerçekleştirildi (zayıf:1, orta:2, kuvvetli:3). İkili kıyaslamalarda, Kontrol ve Curcumin grubu arasında, Radyasyon ve Radyasyon+Curcumin grubu arasında H-skorun anlamlı bir farklılık göstermediği tespit edildi. Radyasyon uygulanan gruplar ile diğer gruplar kıyaslandığında, radyasyona bağlı olarak H-skorun anlamlı $(p<0.001)$ düzeyde arttığı saptandı. (Tablo 2).

\section{Kontrol ve Deney Gruplarında Spermatogenezin Johnsen Skoru ile Değerlendirilmesi}

Testiste radyasyona bağlı olarak, seminifer tübül duvarında spermatogenezde meydana gelen değişiklikleri ve curcuminin profilaktik kullanımına bağlı olarak ortaya çıkabilecek muhtemel iyileşmeyi değerlendirmek için $\mathrm{H}$-E ile boyanmış testis preparatları üzerinde, Johnsen kriterlerine göre semikantitatif olarak skorlama yapıldı. İstatistiksel analizler neticesinde, ikili kıyaslamalarda, Kontrol ve Curcumin grubu arasında, Radyasyon ve Radyasyon+Curcumin grubu arasında Johnsen skorunun anlamlı bir farklılık gös- termediği tespit edildi. Radyasyon uygulanan gruplar ile diğer gruplar kıyaslandığında, radyasyona bağlı olarak Johnsen skorunun anlamlı düzeyde $(p<0.001)$ azalmış olduğu görüldü (Tablo 3).

\section{Seminifer Tübüllerin Morfometrik Olarak Değerlendirilmesi}

Tüm gruplarda seminifer tübül çapları ve seminifer epitel yükseklikleri ölçülerek, istatistiksel olarak analiz edildiğinde; radyasyona bağlı olarak seminifer tübül çaplarının belirgin bir şekilde azaldığı, yine epitelin de belirgin düzeyde inceldiği tespit edildi. ỉkili kıyaslamalarda hem epitel yüksekliği, hem de seminifer tübül çapı açısından, Kontrol ve Curcumin grubu arasında, Radyasyon ve Radyasyon+Curcumin grubu arasında anlamlı bir farklılık olmadığı görüldü. Radyasyon uygulanan gruplar ile diğer gruplar kıyaslandığında, radyasyona bağlı olarak seminifer epitel yüksekliğinde ve çapında anlamlı düzeyde $(p<0.001)$ azalma olduğu saptandı (Tablo 4).

Tablo 2 PARP-1 immünreaktivitesi için histolojik skor değerleri.

\begin{tabular}{|l|l|l|l|l|}
\hline & \multicolumn{1}{|c|}{$\begin{array}{c}\text { Kontrol } \\
\mathbf{n}=6\end{array}$} & \multicolumn{1}{|c|}{$\begin{array}{c}\text { Curcumin } \\
\mathbf{n}=6\end{array}$} & \multicolumn{1}{|c|}{$\begin{array}{c}\text { Radyasyon } \\
\mathbf{n}=6\end{array}$} & \multicolumn{1}{c|}{$\begin{array}{c}\text { Radyasyon+Curcumin } \\
\mathbf{n}=6\end{array}$} \\
\hline $\begin{array}{l}\text { PARP-1 için } \\
\text { H-Skor }\end{array}$ & $\begin{array}{l}254.50 \\
(243.75-262.75)\end{array}$ & $\begin{array}{l}263.50 \\
(259.25-268.50)\end{array}$ & $\begin{array}{l}285.50 \\
(276.75-292.00)^{\mathrm{a}}\end{array}$ & $\begin{array}{l}279.00 \\
(276.50-281.75)^{\mathrm{a}}\end{array}$ \\
\hline
\end{tabular}

Veriler ortanca (25-75 persantil) olarak sunulmuştur.

$p<0.05$ olduğunda istatistiksel olarak anlamlı kabul edilmiştir. ${ }^{a} p<0.001$ Kontrol ve Curcumin grubu ile kıyaslandığında.

Tablo 3 Tüm gruplara ait Johnsen skor analizleri.

\begin{tabular}{|l|c|c|c|c|}
\hline & $\begin{array}{c}\text { Kontrol } \\
\mathbf{n = 1 0}\end{array}$ & $\begin{array}{c}\text { Curcumin } \\
\mathbf{n = 9}\end{array}$ & $\begin{array}{c}\text { Radyasyon } \\
\mathbf{n = 9}\end{array}$ & $\begin{array}{c}\text { Radyasyon+Curcumin } \\
\mathbf{n = 9}\end{array}$ \\
\hline $\begin{array}{l}\text { Johnsen } \\
\text { Skoru }\end{array}$ & $9.8(9.70-9.83)$ & $9.8(9.65-9.90)$ & $4.9(4.80-5.15)^{\mathrm{a}}$ & $5.1(5.00-5.15)^{\mathrm{a}}$ \\
\hline
\end{tabular}

Veriler ortanca (25-75 persantil) olarak sunulmuştur.

$p<0.05$ olduğunda istatistiksel olarak anlamlı kabul edilmiştir.

${ }^{a} p<0.001$ Kontrol ve Curcumin grubu ile kıyaslandığında. 


\section{Deneklerin Vücut Ağırlığında ve Testis Ağırlığında Meydana Gelen Değişiklikler}

Deneyin başlangıcında, radyasyon uygulamasından 24 saat sonra ve sakrifikasyondan hemen önce tartılan deneklerin ağırlıkları istatistiksel olarak analiz edildiğinde, tüm gruplarda kendi içinde 3 farklı zaman diliminde ölçülen ağırlıkların anlamlı düzeyde farklılık gösterdiği saptandı $(p<0.001)$. Ikili kıyaslamalarda kontrol ve curcumin grubunun, radyasyon ile de radyasyon+curcumin grubunun ağırlıklarının benzer olduğu tespit edildi. Skrotal uygulanan radyasyona bağlı olarak deneklerin vücut ağırlığında herhangi bir azalma olmadığı, buna keza, genç erişkin olan deneklerin 7 haftalık deney süresi boyunca ağırlıklarında meydana gelen doğal artıştan dolayı, grup içi ağırlık değişikliklerinde anlamlı artış olduğu tespit edildi (Tablo 5).

\begin{tabular}{|l|c|c|c|c|}
\hline & $\begin{array}{c}\text { Kontrol } \\
\mathbf{n = 1 0}\end{array}$ & $\begin{array}{c}\text { Curcumin } \\
\mathbf{n = 9}\end{array}$ & $\begin{array}{c}\text { Radyasyon } \\
\mathbf{n = 9}\end{array}$ & $\begin{array}{c}\text { Radyasyon+Curcumin } \\
\mathbf{n}=\mathbf{9}\end{array}$ \\
\hline $\begin{array}{l}\text { Seminifer } \\
\text { tübül çapı } \\
(\boldsymbol{\mu})\end{array}$ & $\begin{array}{c}314.05 \\
(300.2-317.6)\end{array}$ & $\begin{array}{c}317.60 \\
(303.0-324.2)\end{array}$ & $\begin{array}{c}192.40 \\
(181.8-209.8)^{\mathrm{a}}\end{array}$ & $\begin{array}{c}194.80 \\
(180.1-215.6)^{\mathrm{a}}\end{array}$ \\
\hline $\begin{array}{l}\text { Seminifer } \\
\text { epitel yük- } \\
\text { sekliği }(\boldsymbol{\mu m})\end{array}$ & 77.25 & 78.00 & 55.80 & 55.20 \\
\hline
\end{tabular}

Veriler ortanca (minimum-maksimum) olarak sunulmuştur. $\mathrm{p}<0.05$ olduğunda istatistiksel olarak anlamlı kabul edilmiștir. ${ }^{a} p<0.001$ Kontrol ve Curcumin grubu ile kıyaslandığında. ${ }^{b} p<0.001$ Kontrol ve Curcumin grubu ile kıyaslandığında

\begin{tabular}{|c|c|c|c|c|}
\hline & $\begin{array}{c}\text { Kontrol } \\
n=10\end{array}$ & $\underset{n=9}{\substack{\text { Curcumin } \\
n}}$ & $\begin{array}{c}\text { Radyasyon } \\
n=9\end{array}$ & $\begin{array}{c}\text { Radyasyon+Curcumin } \\
n=9\end{array}$ \\
\hline $\begin{array}{l}\text { Başlangıç denek } \\
\text { ağırlığı }\end{array}$ & $\begin{array}{c}271.50 \\
(250-281)\end{array}$ & $\begin{array}{c}273.00 \\
(258-294)\end{array}$ & $\begin{array}{c}290.00 \\
(275-298)\end{array}$ & $\begin{array}{c}296.00 \\
(285-300)\end{array}$ \\
\hline $\begin{array}{l}\text { Işınlama sonrası } \\
\text { denek ağırlığı } \\
\text { (1. Gün) }\end{array}$ & $\begin{array}{c}298.50 \\
(265-310)\end{array}$ & $\begin{array}{c}295.00 \\
(285-322)\end{array}$ & $\begin{array}{c}307.00 \\
(300-330)\end{array}$ & $\begin{array}{c}313.00 \\
(296-322)\end{array}$ \\
\hline $\begin{array}{l}\text { Sakrifikasyon } \\
\text { denek ağırlığı }\end{array}$ & $\begin{array}{c}363.50 \\
(349-385)\end{array}$ & $\begin{array}{c}367.00 \\
(348-384)\end{array}$ & $\begin{array}{c}386.00 \\
(336-411)^{a}\end{array}$ & $\begin{array}{c}377.00 \\
(355-405)^{\mathrm{a}}\end{array}$ \\
\hline $\begin{array}{l}\text { Testis ağırlığı } \\
\text { (gr)/100gr vücut } \\
\text { ağırlığı }\end{array}$ & $\begin{array}{c}0.366 \\
(0.315-0.414)\end{array}$ & $\begin{array}{c}0.394 \\
(0.357-0.426)\end{array}$ & $\begin{array}{c}0.135 \\
(0.115-0.149)^{a}\end{array}$ & $\begin{array}{c}0.133 \\
(0.101-0.143)^{a}\end{array}$ \\
\hline
\end{tabular}


Skrotal ışınlamaya bağlı olarak radyasyon ve radyasyon+curcumin gruplarında, testis ağırıklarında kontrol ve curcumin gruplarına kıyasla anlamlı düzeyde $(p<0.001)$ bir azalma olduğu tespit edildi (Tablo 5).

\section{Tartışma}

Çalışmamızda 6 Gy $X$ ışını skrotal bölgeye tek seferde uygulanmış olup, ışınlamadan 6 hafta sonra, deneklerden elde edilen testis dokusu örneklerinde, öncelikle genel morfoloji değerlendirilmiş, ardından radyasyona bağlı seminifer tübüllerdeki hasar; hem histomorfometrik ölçümler ile hem de Johnsen skoru ile semikantitatif olarak analiz edilmiştir. Radyasyonun direkt etki ile oluşturduğu DNA hasarı ve indirekt serbest radikaller üzerinden meydana getirdiği hücresel hasarda PARP-1 imminoreaktivitesindeki değişiklikler immünohistokimyasal yöntemle değerlendirilmiștir. Ayrıca bu süreçte ışınlamadan 1 hafta önce profilaktik olarak uygulanmaya başlayan curcuminin (100 mg/kg) etkinliği de araştırılmıştır.

Radyoterapi, testis kanseri tedavisinde, özellikle evre I seminomlarda, başarı oranı \%100'lere varan bir tedavi yöntemi olarak uzun yıllardır kullanılmaktadır. Amerika Birleşik Devletlerinde yapılan bir epidemiyolojik çalışmada testis tümörlü hasta sayısının 1973 yılından günümüze kadar \% 44 arttığı ve bunların içinde de en fazla artan hastalık grubunun \% 64 ile seminomlar olduğu rapor edilmiştir. Bu nedenle testis tümörlü, hastalarda radyoterapi uygulamalarının daha da artacağı öngörülmüştür (18).

Radyasyonun insandaki spermatogenetik siklusta oluşturduğu negatif etkiler çeşitli deney modellerinde gösterilmiştir. Radyoterapi görecek erişkin testis kanserli hastalarda infertilite oluşumuna karşı radyoterapi öncesi sperm dondurma gibi farklı işlemler uygulanmaktadır $(7,19)$. Fakat hasta populasyonunda sadece erişkinler değil puberteye ulaşmamış çocuklarda bulunmaktadır. Kanser tedavisinden sonra hastaların çocuk sahibi olması için radyasyonun üreme fonksiyonu üzerine olan zararına karşı koruyucu tekniklerin geliştirilmesi zaruri bir intiyaçtır.

Skrotal radyoterapi uygulanan erkek hastalarda spermatogenezin bozulduğu, kalıcı veya uygulanan doz oranına göre kısa ya da uzun süreli infertilite oluştuğu belirtilmiştir (20). Bu bağlamda, infertilite çok büyük bir klinik problemdir. İstatistiklere göre Amerika'da ki çiftlerin \%15 i infertildir ve bunların da \%15 inin nedeni oksidatif strestir. Bundan dolayı son yıllarda infertilite ve oksidatif stres ile ilgili birçok çalışma yapılmıştır (21).

Kanserin iyonizan radyasyon ile tedavisinde terapötik kazancı arttırmanın bir yolu, antitümöral etkinliği değiştirmeksizin normal dokuları radyasyon hasarından koruyan hücre koruyucu ajanların kullanılmasıdır (4). İyi bir antioksidan, antikanser, normal hücrelere selektif radyoprotektör bir ajan olan curcumini ışınlamadan 1 hafta önce başlayarak, 7 hafta boyunca, gün aşırı oral olarak $100 \mathrm{mg} / \mathrm{kg}$ dozda profilaktik olarak uyguladığımız bu çalışmada; curcuminin radyasyona bağlı ortaya çıkan histopatolojik, histomorfometrik ve immünohistokimyasal düzeyde değerlendirdiğimiz parametreleri nasıl etkilediğini araştırdık.

Curcuma longa bitkisinin rizomlarından elde edilen curcumin hücre koruyucu ajanlar içerisinde major fenolik yapıda bir birleşiktir (22). Curcumin anti-inflamatuar, antioksidan, yara iyileştirici, antikanser, antimikrobiyal aktivite gibi geniş bir farmakolojik kapasiteye sahip olduğu bilinmektedir (23).

Yapılan literatür incelemelerinde, curcuminin skrotal uygulanan iyonize radyasyona karşı radyoprotektif etkisinde PARP-1 immünoreaktivitesinin araştırıldığı herhangi bir çalışmaya rastlanmamıştır. Skrotal bölgeye uygulanan 6 Gy'lik iyonize radyasyonun, sıçan testislerinde çeşitli morfolojik hasarlara neden olduğu görülmüştür. Işınlamadan 6 hafta sonra, bu hasarlar ışık mikroskobik düzeyde incelendiğinde; seminifer tübüllerde germinal hücre tüketimi, spermatogenezin durması, bazal lamina kalınlaşması, tübüllerde vakuolizasyon, tunika albugineada kalınlaşma, seminifer tübül epitelinde sadece Sertoli hücreleri ve tek tük rezerv spermatogonyumlara rastlanması ve pek çok atrofik tübül yapısının gelişmesi şeklinde sıralanabilir. Bizim bulgularımız direkt skrotal veya pelvik alan ışınlama yapılan çalışmalarda gözlenen histolojik hasarlar ile uygunluk göstermektedir.

Testis farklı tipte veya farklı evrelerdeki farklılaşan 
hücrelerden oluşur. Bu hücrelerin hepsi radyasyona karşı farklı hassasiyetler gösterir. Radyasyon sonrası seminifer tübüllerin bir kısmında atrofi gözlenir. Atrofik tübül sadece Sertoli hücrelerinden oluşabileceği gibi nadiren germ hücreleri ve Sertoli hücreleri veya çok az sayıda hücresel bağlantıları olmayan germ hücreleri ve Sertoli hücrelerinden de oluşabilir. Işınlama sonrası radyasyon spermatogonyumların farklılaşmasını bozar ve spermatogenezi baskılar. Bu yüzden sadece tübüllerde görülen tek germ hücresinin rezerv spermatogonyumlar olduğu bildirilmiştir (24).

Çalışmamızda radyasyon alan grupların her ikisinde de atrofik tübüller gözlenmiştir. Çalışmamız tek zamanlı bir çalışma olduğundan, farklı zaman dilimlerinde zamana bağlı değişimleri saptamamız mümkün olmamıştır, ancak farklı zaman dilimlerinde spermatogenezin değerlendirildiği çalışmalarda da atrofik tübül morfolojisinin zamana ve radyasyonun dozuna göre değişiklik gösterdiği pek çok çalışmada ortaya konmuştur. Atrofinin aktif olarak bölünen germ hücrelerinin serbest radikallerin hasarlayıcı etkisine maruz kalması sonucu oluştuğuna inanılmaktadır. Meistrich ve ark. (25), yaptıkları bir çalışmada sıçanlara 3,5 Gy skrotal radyoterapi uygulamışlardır. 10 hafta sonra sakrifiye edilen deneklerin testis doku örnekleri ışık mikroskobik düzeyde incelendiğinde, çoğu seminifer tübülde sadece Sertoli hücrelerinin kaldığı, kimi tübüllerde ise Sertoli ve tip A spermatogonyumların hayatta kaldığı görülmüştür. Testis ağırlıklarında ve tübül çaplarında düşüşler gözlendiğini bildirmişlerdir. Ayrıca testislere uygulanan 1-3 Gy gibi düşük dozlardaki radyasyonun bile farklılaşan spermatogonyumları tahrip ettiği, bunun sonucunda ise, spermatogenetik hücrelerde ileri düzeyde bir azalmanın ortaya çıktığı bildirilmiştir. Kök spermatogonyumların ise çok daha fazla radyoresistans olduğu belirtilmiştir. İnsanlara uygulanan 2 Gy radyasyonun bile 50 haftaya kadar ya da daha fazla sürebilecek bir azospermiye neden olabileceği ileri sürülmüştür. Bunun nedeninin ise germ hücrelerin haraplanması ve farklılaşma özelliklerini geçici süre kaybetmesi olarak bildirilmiştir (25). Çalışmamızda; Meistrich'in çalışmasına paralel olarak seminifer tübüllerde sadece Sertoli hücreleri ve çok az sayıda kök spermatogonyumlara rastlanmıştır. Spermatogenizi değerlendirdiğimiz Johnsen skorlaması sonuçlarının istatistiksel analizleri de radyas- yona bağlı olarak germinal epitelde meydana gelen hücre kaybının çok ciddi boyutta olduğunu açık bir şekilde ortaya koymuştur. Kontrol ve Curcumin grubu deneklerimizde tespit edilen Johnsen skoru değerlerini, Radyasyon ve Radyasyon+curcumin grupları ile kıyasladığımızda, radyasyona bağlı olarak skorlarda anlamlı bir azalma olduğu saptanmıştır.

Andrieu ve ark. (26), yaptıkları bir çalışmada wistar albino erkek sıçanların testislerine 6 Gy lokal radyasyon uygulanmıştır. 3 hafta sonra hayvanlar sakrifiye edilmiş ve testisler incelenmek üzere çıkarılmıştır. Radyasyon grubunda testis ağırlığının belirgin şekilde düştüğü gözlenmiştir. Işık mikroskobik incelemelerde radyasyon alan deneklerin testis çapında ve seminifer tübül epitelinin yüksekliğinde azalma olduğu tespit edilmiştir. Ayrıca seminifer tübüllerde yapılan hücre sayımı neticesinde kontrol grubundaki spermatogonyum ve primer spermatosit sayılarının radyasyon grubunda anlamlı bir düşüş gösterdiği bildirilmiştir. Bu çalışmanın verileri ile bizim verilerimiz büyük oranda paralellik göstermekle birlikte, seminifer tübüllerde tespit edilen hücre sayılarının yüksekliği sakrifikasyon zamanının çalışmamızın sakrifikasyon zamanından 3 hafta erken olmasından dolayı ve maturasyon-tüketim proçesinin zamana bağlı olarak gerçekleşmesindendir (26). Radyasyon uygulandıktan sonra germ hücrelerinden geriye kök hücreler, spermatositler ve spermatidler hayatta kalır. Spermatosit ve spermatidler de maturasyon ile tükenir. Normalde mitotik aktivitesi olmayan kök hücreler, hücre tüketimini takiben çoğalmaya ve seminifer epitelini tekrardan oluşturmaya başlar $(25,27)$.

Hussein ve ark. (28), radyasyonun üreme sistemi üzerindeki ciddi hasarlayıcı etkisini wistar albino sıçanlara tüm vücud 8 Gy radyasyon uyguladıkları çaIışmalarında ortaya koymuşlardır. Radyoterapiden 48 saat sonra denekleri sakrifiye ettiklerinde, spermatogenetik seri hücrelerinin hasarlandığını, özellikle spermatositler ve spermatidlerin azaldığını, spermatozoaların da tamamen tükendiğini gözlemlemişlerdir. Seminifer tübüllerin çoğunda spermatogenetik seri hücrelerin düzensiz nükleuslara sahip olduğu ve sitoplazmalarında asitofilik vakaollerin bulunduğunu bildirmişlerdir. Ayrıca Sertoli ve Leydig hücrelerinin sayılarında ciddi azalma ile birlikte testis ağırlıkları ve 
seminifer epitel yüksekliklerinde de anlamlı bir şekilde düşüş yaşandığını tespit etmişlerdir (28). Sharma ve ark. (29), yaptıkları bir çalışmada Swiss albino farelere 7,5 Gy gama radyasyonu uygulamışlar ve testisleri histopatolojik olarak incelemişlerdir. Ilk olarak, radyasyon alan deneklerin seminifer tübül çaplarında anlamlı bir azalış olduğunu tespit etmişlerdir. Farelerin testislerinin ışık mikroskobisinde; tahrip olmuş tübüller, epitelde pul pul dökülmeler, tübüller arası ödem, nükleus parçalanmaları, piknotik çekirdekler, nekrotik hücreler ve degranuler sitoplazmalar gözlemlemişlerdir. Yine bu çalışmalarında infertilitenin önemli bir tıbbı ve sosyal sorun olduğunu, fitokimyasal ajanların radyasyondan koruyucu etkilerini kullanarak testiküler germ hücrelerini radyasyondan korumanın mümkün olabileceğini ileri sürmüşlerdir (29). Çalışmamızda da literatürdeki verilere uyumlu olarak radyasyon alan gruplardaki deneklerin testis ağırlıklarında, seminifer tübül çaplarında ve germinal epitel yüksekliklerinde, Kontrol ve Curcumin gruplarına kıyasla istatistiksel olarak anlamlı bir düşüş gözlenmiştir.

Curcuminin antioksidan ve radyoprotektör özelliklerinin araştırıldığı pek çok deneysel model kurgulanmış ve pek çok çalışma yapılmıştır $(30,31)$. Sharaf ve ark. (32), çalışmalarında albino sıçanların testislerine 3 gün ardı ardına yarım saat boyunca 900 joule lük ultraviyole $C$ ışını uygulamışlardır ve curcuminin farklı dozlardaki koruyuculuğunu araştırmışlardır. 4 ayrı gruba 3 gün ardı ardına ultraviyole C ışını verdikten sonra tedaviye başlamışlardır. Gruptan ilk olanı kontrol olarak tutulmuştur. Diğer 3 gruba ise sırasıyla $5 \mathrm{mg} / \mathrm{kg}, 25 \mathrm{mg} / \mathrm{kg}$ ve $50 \mathrm{mg} / \mathrm{kg}$ curcumin 4 hafta boyunca uygulanmıştır. Deneyin sonunda hayvanlar sakrifiye edilmiş ve yapılan histopatolojik incelemeler neticesinde $5 \mathrm{mg} / \mathrm{kg}$ curcumin tedavili ultraviyole verilen grupta birçok seminifer tübül normal olarak saptanmıştır. Bununla birlikte bazı bölümlerindeki intersitisyel bağ doku alanlarında vakouller ve kimi Sertoli hücreleri arasında açıklıklar görülmüştür. Genel görüntüsü kontrol grubuna benzeyen seminifer tübüller bu grupta izlenmiştir. Buna karşın; 25 mg/kg ve 50 $\mathrm{mg} / \mathrm{kg}$ curcumin tedavili sıçanlarda; spermatogenetik seri hücreleri arasındaki boşlukların daha fazla olduğu, spermatositlerin normal morfolojik görünümden yoksun olduğu ve spermatogenetik hücrelerde tükenmeler olduğu gözlenmiştir. 50 mg/kg curcumin teda- vili grupta bunlara ilave olarak, bazal laminada kalınlaşmalar ile spermatogenetik seri hücrelerde pul pul dökülmeler ve düzensiz yerleşimli seri hücreler gözlenmiştir. Bu çalışmada $5 \mathrm{mg} / \mathrm{kg}$ curcumin dozunun ultraviyole ışınlarına karşı iyi koruma sağladığı, buna karşın yüksek dozlarda uygulanan curcuminin düşük doz kadar iyi koruyucu etki göstermediği bildirilmiştir (32). Buradan curcumin gibi kullanılan koruyucu-iyileştirici ajanların dozu kadar, toksik ajanın dozunun da hasarın engellenmesinde ya da onarılmasında ne kadar önemli olduğu sonucuna varılabilir.

Çalışmamızda uyguladığımız $100 \mathrm{mg} / \mathrm{kg}$ curcumin dozu çeşitli radyasyon çalışmalarından yararlanılarak seçilmiş olup, skrotal radyoterapide uyguladığımız dozda curcuminin istatistiksel olarak anlamlı bir koruma sağlamadığı tespit edilmiştir. Gerek morfometrik ölçümlerle birlikte testis ağırlıklarında, gerekse spermatogenezi değerlendirdiğimiz Johnsen skorlamasında radyasyon grubuna kıyasla kısmen olumlu veriler elde edilmiş olsa da, fark istatistiksel olarak anlamlı düzeyde bulunmamıştır.

Son yıllarda yoğun bir şekilde çalışılan, erkek infertilitesinin etiyolojisinde önemli bir rol oynayan, DNA hasarına karşı oluşan PARP-1 immünoreaktivitesi de değerlendirilmiştir.

Son yıllarda PARP-1 enziminin erkek germ hücrelerinin farklılanmasında anahtar rol oynadığı belirtilmiştir (33). PARP oksidatif stres ile indüklenmiş erkek üreme rahatsızlıklarında yüksek aktivite gösterir. İnsan germ hücrelerindeki PARP-1 çalışmaları son yıllarda önem kazanmıştır. PARP üzerindeki çalışmalar çoğunlukla kemirgenler üzerinde yapılmıştır ve bu çalışmaların çoğunda PARP ın spermatogonyum ve pakiten nükleuslu spermatositlerde lokolize olduğu bildirilmiştir (34). Bizde immünohistokimyasal yöntemle deney gruplarımızda PARP-1 ekspresyonunu H-skorlama ile değerlendirirken, spermatogonyumlardaki lokalizasyonu ve boyanma şiddetlerini göz önünde bulundurduk. İkili kıyaslamalarda, Kontrol ve Curcumin grubu arasında, Radyasyon ve Radyasyon+Curcumin grubu arasında H-skorun anlamlı bir farklılık göstermediğini saptadık. Radyasyon uygulanan gruplar ile diğer gruplar kıyaslandığında, radyasyona bağlı olarak H-skorun anlamlı $(p<0.001)$ düzeyde artmış olduğunu gözlemledik. Bu bulguların radyasyona 
bağlı meydana gelen direkt DNA ve indirekt serbest radikal aracılı hücresel hasarın şiddetini açıkça ortaya koyduğunu düşünmekteyiz. Spermatagoniumların PARP-1 enzim aktivitesinin yüksek olmasının DNA yapısının korunmasında oldukça önemli olduğu yapılan çalışmalarda ortaya konmuştur (35). Curcuminin profilaktik kullanımı da PARP-1 immünoreaktivitesi açısından tedavisiz gruba kıyasla anlamlı bir fark yaratmamıștır. Radyasyon+Curcumin grubunda yer alan deneklerimizin gerek genel morfolojik bulguları gerekse histomorfometrik ve histopatolojik bulguları, kullandığımız dozda beklenen koruma ve iyileşmenin ortaya çıkmadığını gözler önüne sermektedir.

Oksidan-antioksidan dengenin bozulmasına yol açan çeşitli deneysel modellemelerde de PARP-1 immünoreaktivitesinin ortaya çıkan serbest radikaller nedeniyle artış gösterdiği ispatlanmıştır. Tekcanve ark. (36), varikoselle indükledikleri testis hasarında PARP-1 immünoreaktivitesinin oksidatif stresle ilişkili olduğunu rapor etmişlerdir. Bu deney modelinde PARP yolaklarını incelemiş̧lerdir. İmmün boyamalarda varikoselli sıçanlarda seminifer tübüllerdeki PARP ve PARP-1 in spermatogonyum ve primer spermatositlerdeki lokasyonunda sham ve kontrol grubuna göre güçlü boyanma olduğunu göstermişlerdir. Western blotlama yöntemi kullanırak varikoselli sıçanlarda yüksek PARP aktivitesi olduğu kanıtlanmış olup PARP bandı yanında apoptotik bantlara da rastlanmıştır (36).

Maymon ve ark. (37), çalışmalarında PARP ve PARP_ 1 aktivasyonunun ağırlıklı olarak germ hücrelerinde olduğunu ve testislerdeki somatik hücrelerde lokalize olmadığını bildirmişlerdir. Araştırmacılar farklı spermatogenez evrelerinde PARP'ın rolünü incelemişler ve PARP expresyonunun uzayan spermatidlerde belirgin olarak görülmesinin, PARP'ın kromatin modellenmesi ve spermatid nükleer yoğunluğu ile ilişkisi olabileceğini belirtmişlerdir (37). Eğer radyoterapi sırasında germ hücrelerinde radyasyonun tahrip edici etkisini önleme yeteneğine sahip hücre koruyucu etkili bir ajan kullanılabilirse, radyasyonun azospermi ve infertilite gibi üreme sağlığı üzerindeki etkileri önlenebilir ve radyoterapi alan genç erkek hastaların yaşam kalitesi üzerinde olumlu bir etki sağlanabilir.

Bu bağlamda koruyucu olabileceğini düşündüğümüz, ancak kullandığımız dozda etkin bir koruma ve iyileşme sağlayamayan, curcuminin yeni planlanacak doz kontrollü çalışmalar ile radyoprotektif etkin dozunun araştırılmasına intiyaç olduğunu, optimum terapötik dozun saptanması ile kliniğe katkı sağlanabileceğini düşünmekteyiz.

\section{Teşekkür}

Bu çalışma Bülent Ecevit Üniversitesi Bilimsel Araştırma Projeleri tarafından desteklenmiştir (Proje No: 2012-42-00-03).

\section{Kaynaklar}

1. Coşkun Ö. İyonize radyasyonun biyolojik etkileri. SDU Tecnical Sciences Vocational School 2011; 1(2): 13-17.

2. Eker L, Acar AO, Demirkan N. Hastaların radyasyon üzerindeki bilgi düzeyleri. MYO-OS 2010- Ulusal Meslek Yüksekokulları Öğrenci Sempozyumu, Düzce. 2010; 21-22.

3. Take G, Erdogan D, Helvacioglu F, Göktas G, Ozbey G, Uluoglu C, Yücel B, Guney Y, Hicsonmez A, Ozkan S. Effect of melatonin and time of administration on irradiation induced damage to rat testes. Braz J Med Biol Res 2009; 42: 621-628.

4. Karakoyun Ö, Aras A, Tuğan D, Hekimgil M, Yalman D, Esassolak M, Haydaroğlu A. The relationship between radiation-induced apoptosis in rat germ cells and amifosine. T Klin J Med Sci 2004;24: 142-146.

5. Zhang Z, Shao S, Meistrich ML. The radiation induced block in spermatogonial differentiation is due to damage to the somatic environment, not the germ cells. J. Cell. Physiol 2007; 211(1): 149-158.

6. Oakberg EF. Sensitivity and time of degeneration of spermatogenic cells irradiated in various stages of maturation in the mouse. Rad Res 1955; 2: 369391.

7. Aslam I, Fishel S, Moore H, Dowell K, Thornton $\mathrm{S}$. Fertility preservation of boys undergoing anti-cancer therapy: a review of the existing situation and prospects for the future. Hum Reprod 2000; 15(10): 2154-2159.

8. Akpolat M, Topçu Tarladaçalışır Y, Uz YH, Sapmaz Metin M, Kızılay G. Kanser tedavisinde curcuminin yeri. Yeni Tıp Dergisi 2010; 27: 142-147. 
9. Kanter M, Topçu Tarladaçalışır Y, Akpolat M, Mercantepe $\mathrm{T}$. Gamma radyasyona bağlı oluşan jejunum mukoza hasarına karşı curcumin ve amifostinin koruyucu etkilerinin incelenmesi. Tıp Araştırmaları Dergisi 2008; 6(3): 128-135.

10. Akpolat M, Kanter M, Uzal MC. Protective effects of curcumin against gamma radiation-induced ileal mucosal damage. Arch Toxicol 2009; 83(6): 609-617.

11. Noorafshan A, Ashkani-Esfahani S. A review of therapeutic effects of curcumin. Curr Pharm Des 2013; 19(11): 2032-2046.

12. Çimen Özgen S, Dökmeci D, Akpolat M, Karadağ ÇH, Gündüz Ö, Erbaş H, Benian Ö, Uzal C, Turan FN. The Protective Effect of Curcumin on Ionizing Radiation-induced Cataractogenesis in Rats. Balkan Med J 2012; 29: 358-363.

13. Topçu-Tarladaçalışır Y, Akpolat M, Uz YH, Kızılay G, Sapmaz-Metin M, Cerkezkayabekir A, Kurt-Omurlu I. Effects of Curcumin on Apoptosis and Oxidoinflammatory Regulation in Rat Model of Acetic Acid-induced Colitis: Role of JNK and p38 MAPK. Journal of Medicinal Food 2013; 16(4): 296-305.

14. Schreiber V, Ame JC, Dolle P. Poly(ADP-ribose) polymerase-2 (PARP-2) is required for efficient base excision DNA repair in association with 78PARP-1 and XRCC1. J Biol Chem 2002; 277(25): 23028-23036.

15. Meyer-Ficca ML, Meyer RG, Jacobson EL, Jacobson MK. Poly(ADP-ribose) polymerases: managing genome stability. Int J Biochem Cell Biol 2005; 37(5): 920-926.

16. Rooij DG, Kant HJ, Dol R, Wagemaker G, van Buul PP, van Duijn-Goedhart A, de Jong FH, Broerse $\mathrm{JJ}$. Long term effects of irrradiation before adulthood on reproductive function in the male Rhesus monkey. Biol Reprod 2002; 66(2): 486494.

17. Johnsen SG. Testicular biopsy score count- a method for registration of spermatogenesis in human testes: normal values and results of 335 hypogonadal males. Hormones 1970; 1(1): 2-25.

18. Akbal C, Tanıdır Y, Turkeri L. Testis kanseri ve infertilite. Üroonkoloji Bülteni 2006; 4: 8-11.

19. Otala M, Suomalainen L, Pentikäinen MO, Kovanen P, Tenhunen M, Erkkila K, Toppari J, Dunkel L. Protection from radiation-induced male germ cell loss by Sphingosine-1-Phosphate. Biol Reprod 2003; 70(3): 759-767.

20. Schally AV, Paz-Bouza JI, Schlosser JV, Karashima T, Debeljuk L, Gandle B, Sampson M. Protective effects of analogs of luteinizing hormone-releasing hormone against x-radiation-induced testicular damage in rats. Proc. Nati. Acad. Sci 1987; 84(3): 851-855.

21. Makker K, Agarwal A, Sharma R. Oxidative stress and male infertility. Indian J Med Res 2009; 129(4): 357-367.

22. Sebastiaa N, Montorob A, Montoroa A, Almonacidb M, Villaescusab JI, C. Jose, Suchc E, Sillac MA, Sorianoa JM, Assessment in vitro of radioprotective efficacy of curcumin and resveratrol. Radiat Meas 2011; 46(9): 962-966.

23. Noorafshan A, Karbalay Doust $S$, Valizadeh A, Aliabadi E, Mirkhani $\mathrm{H}$. Ameliorative effects of curcumin on the seminiferous epithelium in metronidazole-treated mice: a stereological study. Toxicol Pathol 2010; 38(3): 366-371.

24. Shetty G, Wilson G, Hardy MP, Niu E, Huhtaniemi I, Meistrich ML. Inhibition of recovery of spermatogenesis in irradiated rats by different androgens. Endocrinology 2002; 143(9): 3385-3396.

25. Meistrich ML, Kangasniemi M. Hormone treatment after irradiation stimulates recovery of rat spermatogenesis from surviving spermatogonia. J Androl 1997; 18(1): 80-87.

26. Nalca Andrieu M, Kurtman MC, Hicsonmez A, Özbilgin $\mathrm{K}$, Eser $\mathrm{E}$, Erdemli $\mathrm{E}$. In vivo study to evaluate the protective effects of amifostine on radiation-induced damage of testis tissue. Oncology 2005; 69(1): 44-51.

27. Peltola V, Parvinen M, Huhtaniemi I, Kulmala J, Ahotupa M. Comparison of effects of 0.5 and 3.0 Gy X-irradiation on lipid peroxidation and antioxidant enzyme function in rat testis and liver. J Androl 1993; 14(4): 267-274.

28. Hussein MR, Abu-Dief EE, Abou El-Ghait A, Adly MA, Abdelraheem MH. Morphological evaluation of the radioprotective effects of melatonin against $x$-ray-induced early and acute testis damage in Albino rats: animal model. Int J Exp Path 2006; 87(3): 237-250.

29. Sharma P, Singh R. Protective role of curcumin on lindane induced reproductive toxicity in male Wis- 
tar rats. Bull Environ Contam Toxicol 2010; 84(4): 378-384.

30. Inano H, Onoda M, Inafuku N, Kubota M, Kamada Y, Osawa T, Kobayashi H, Wakabayashi K. Potent preventive action of curcumin on radiation-induced initiation of mammary tumorigenesis in rats. Carcinogenesis 2000; 21(10):1835-1841.

31. Kanter M, Aktas C, Erboga M. Curcumin attenuates testicular damage, apoptotic germ cell death, and oxidative stress in streptozotocin-induced diabetic rats. Mol. Nutr. Food Res 2012; 56:1-8.

32. Sharaf HA, Morsy FA, Shaffie NM, El-Shennawy ATM. Histological and histochemical study on the protective effect of curcumin on ultraviolet irradiation induced testicular damage in albino rats. $\mathrm{J}$ Cytol Histol 2012; 3: 6.

33. Celik-Ozenci C, Tasatargil A, Tekcan M, Sati L, Gungor E, Isbir M, Demir R. Effects of abamectin exposure on male fertility in rats: potential role of oxidative stress-mediated poly(ADP-ribose) polymerase (PARP) activation. Regul Toxicol Pharmacol 2011; 61(3):310-317.

34. Di Meglio S, Denegri M, Vallefuoco S, Tramontano F, Scovassi Al, Quesada P. Poly(ADPR) polymerase-1 and poly(ADPR) glycohydrolase level and distribution in differentiating rat germinal cells. Mol Cell Biochem 2003; 248(1-2):85-91.

35. Tramontano F, Di Meglio S, Quesada P. Co-localization of poly(ADPR)polymerase 1 (PARP-1) poly(ADPR) polymerase 2 (PARP-2) and related proteins in rat testis nuclear matrix defined by chemical cross-linking. J Cell Biochem 2005; 94(1):58-66.

36. Tekcan M, Koksal IT, Tasatargil A, Kutlu O, Gungor E, Celik-Ozenci C. Potential role of poly(ADP-ribose) polymerase activation in the pathogenesis of experimental left varicocele. $\mathrm{J}$ Androl 2012; 33(1):122-132.

37. Maymon BB, Cohen-Armon M, Yavetz H, Yogev $L$, Lifschitz-Mercer B, Kleiman SE, Botchan A, Hauser R, Paz G. Role of poly(ADP ribosyl)ation during human spermatogenesis. Fertil Steril 2006; 86(5):1402-1407. 